\title{
両上顎洞真菌症に合併した真菌性鼻中隔膿瘍例
}

\author{
松見 文晶, 清水 雅子 \\ 公益財団法人星総合病院耳鼻咽喉科
}

鼻中隔膿瘍は日常臨床で遭遇することは少ないが, 鞍鼻や頭蓋内合併症などを来さないよう適切な対応が求 められる。今回我々は, 稀な真菌性鼻中隔膿崵の1例を経験したので報告する。

症例は 89 歳男性。発熱, 鼻根部痛にて前医を受診し急性副鼻腔炎の診断で入院, 抗菌薬治療を受けたが改善 せず, 当科を紹介受診した。鼻背は腫脹し圧痛を認め, 鼻中隔は高度に発赤腫脤していた。副鼻䐅CTでは鼻中 隔前方の腫脹と左上顎洞に石灰化を伴う軟部陰影を認め, 右副鼻胿は全て陰影を認めた。鼻中隔穿刺にて膿が 吸引され鼻中隔膿瘍と診断し, 切開排膿・ドレーン留置と抗菌薬投与を行ったが改善にそしく, 膿からの系状

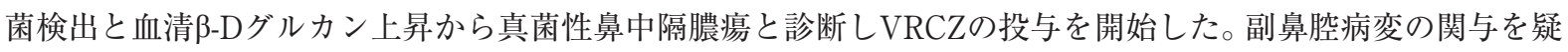
い両ESSと鼻中隔の生検を施行した。両上顎洞内に認めた乾酪様物質は病理学的にAspergillusの菌塊と診断さ れ, 鼻中隔軟骨に真菌浸潤を認めた。後日, 鼻中隔の膿培養からAspergillus fumigatusが同定された。症状軽快 にて第 26 病日退院となったが鞍鼻は残存した。6ヶ月間VRCZ投与を行い，治療終了後も再燃は認めていない。

真菌性鼻中隔膿瘍は易感染性宿主や糖尿病合併例, 副鼻腚真菌症合併例がリスクといえる。これらの背景を 持つ鼻中隔膿瘍患者では，真菌も原因微生物として当初から鑑別に挙げて対応することが必要である。

キーワード：鼻中隔膿瘍，真菌感染，アスペルギルス，上顎洞真菌症，抗真菌薬

\section{A Case of Fungal Nasal Septal Abscess with Bilateral Maxillary Sinus Mycetomas}

\author{
Fumiaki Matsumi, Masako Shimizu \\ Department of Otorhinolaryngology, Hoshi General Hospital
}

Nasal septal abscess is relatively rare, but proper treatment is required to avoid saddle nose deformity and intracranial complications. Herein, we report a rare case of fungal nasal septal abscess with bilateral maxillary sinus mycetomas.

A 89-year-old man presented to the Department of Internal Medicine of a hospital with complaints of fever and nasal pain. He was diagnosed with acute sinusitis by a general physician and admitted to the hospital. Intravenous ceftriaxone and oral azithromycin were administered, but he did not respond well.

He was referred to our hospital for further examination by an otorhinolaryngologist. His nasal septum was severely swollen. Computed tomography showed swelling of the anterior part of the nasal septum and the appearance of soft tissue density shadows in bilateral paranasal sinuses. Needle aspiration of the nasal septum revealed pus and the patient was diagnosed with nasal septal abscess. He underwent surgical drainage under local anesthesia. On the $4^{\text {th }}$ hospital day, serum $\beta$-D glucan was elevated and microorganism-like filamentous fungi were detected in the pus of the nasal septum by direct microscopic examination. These fungi were 
strongly suspected to be the cause of the abscess, and intravenous voriconazole was started, followed by endoscopic sinus surgery and biopsy of the nasal septum. Mycetomas of bilateral maxillary sinuses were diagnosed. Aspergillosis with fungal invasion into septal cartilage was found in a pathological examination. Since Aspergillus fumigatus was cultured from the pus of the nasal septal abscess, the diagnosis of fungal nasal septal abscess was definite. The postoperative course was uneventful and the patient was discharged on $26^{\text {th }}$ hospital day. Oral voriconazole was continued for 6 months and there was no evidence of recurrence 2 months after the end of treatment, but saddle nose deformity remained.

Fungi are rare causes of nasal septal abscess and only a limited number of cases have been reported. From a review of the literature and our case, an immunocompromised status, diabetes mellitus, and paranasal fungal sinusitis (or mycetoma) are high risks for fungal nasal septal abscess. The possibility of fungi as a cause should be considered when a patient with nasal septal abscess has such a history.

Key words : nasal septal abscess, fungal infection, Aspergillus, maxillary sinus fungus ball, antifungal drug

(2016年 12 月 13 日受稿, 2017 年 5 月 2 日受理)

\section{はじめに}

鼻中隔膿瘍は鼻中隔粘膜下に膿貯留を来す疾患であ り, 髄膜炎や海綿静脈洞血栓症などの合併症, 鞍鼻など の後遺症を来し得るが, 抗菌薬の発達した現代では日常 臨床において遭遇することは少なくなった。鼻中隔膿瘍 の原因微生物としては細菌が多くを占め, 真菌によるも のは非常に稀であるが, 後遺症をできるだけ避けるため にも早期の適切な原因同定と治療が重要である。今回, わ れわれは両上顎洞真菌症に合併した稀な真菌性鼻中隔膿 瘍の症例を経験したため文献的考察を踏まえ報告する。

\section{症例}

症例 : 89歳, 男性

主訴：鼻根部痛, 発熱

現病歴：受診約 3 週間前から食欲低下を認め, その頃 より鼻背の腫脹を来していた。9日前に鼻根部痛, 鼻背 腫脹, 発熱にてかかりつけの総合病院内科を受診し, 急 性副鼻腔炎の診断にて入院の上, 抗菌薬治療（セフトリ アキソンナトリウム (CTRX) 点滴 ( $2 \mathrm{~g} /$ 日, 4 日間), ア ジスロマイシン (AZM) 内服 $(500 \mathrm{mg} /$ 日, 3 日間）を受 けたが改善せず，耳鼻咽喉科診察目的に当院紹介となっ た。鼻部外傷のエピソードは認めなかった。

既往歴 : 高血圧, 認知症

初診時現症 : 体温 $37.4^{\circ} \mathrm{C}$, 意識清明。鼻背は腫脹し圧 痛を認めた（図1）。鼻中隔は両側とも発赤腫脹し圧痛を 認め, 波動を触知し, 総鼻道は完全に閉塞しており鼻腔 内の観察はできなかった（図2)。耳， 口腔，咽頭には特 記すべき所見を認めなかった。
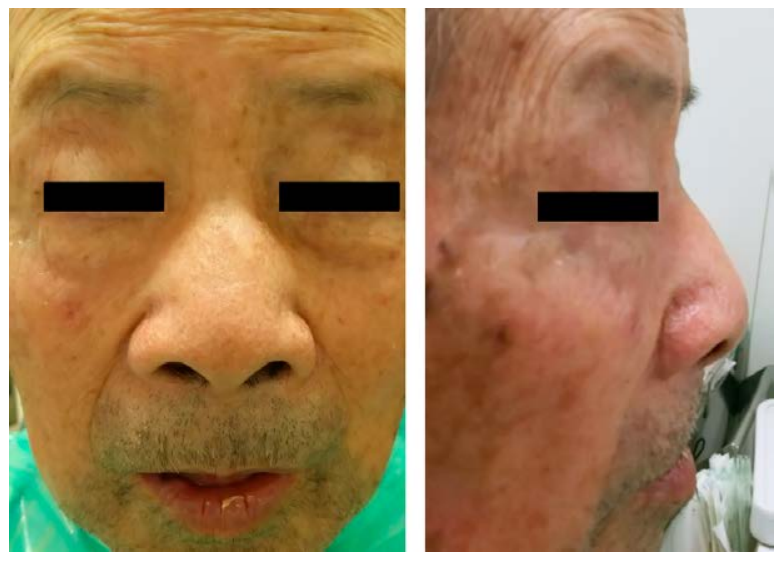

図1 初診時外鼻所見：鼻背の腫脹を認めた。

血液検查所見 (括弧内は正常值):WBC 11200/ $\mu \mathrm{l}(3900$ 〜9800), Neutro 78.6\% (28〜 76), Lymph 10.3\%（17〜 57), $\mathrm{RBC} 378 \times 10^{4} / \mu \mathrm{l}\left(427 \times 10^{4} \sim 570 \times 10^{4}\right), \mathrm{Hb} 10.9 \mathrm{~g} / \mathrm{dl}(13.5$ 17.6), Hct $35 \% \quad(39.8 \sim 51.8)$, Plt $28.5 \times 10^{4} / \mu \mathrm{l}(13.1 \times$ $\left.10^{4} \sim 36.2 \times 10^{4}\right)$, TP $7.0 \mathrm{~g} / \mathrm{dl}(6.7 \sim 8.3), \quad \mathrm{Alb} 3.16 \mathrm{~g} / \mathrm{dl}$ (4.00 5.00), T-bil $0.27 \mathrm{mg} / \mathrm{dl}(0.20 \sim 1.20)$, AST $29 \mathrm{IU} / 1$ (13 33), ALT 35IU/1 (8〜42), LDH 165IU/1 (119 229), BUN $15.1 \mathrm{mg} / \mathrm{dl}(8.0 \sim 22.0)$, Cre $1.19 \mathrm{mg} / \mathrm{dl}(0.60$ 〜 1.10), Na 135mEq/1 (138 146), K 4.5mEq/1 (3.6 4.9), $\mathrm{Cl} 99 \mathrm{mEq} / \mathrm{l} \quad(99 \sim 109)$, CRP 5.92mg/dl ( 0.30), RPR 16 倍, TP抗体（CLIA法）25.65S/CO, HbA1cNGSP 5.8\% (4.6 6.2), HIV抗体陰性, IgG 1668mg/dl (870 1700), IgA 186mg/dl (110 410), IgM 104mg/dl（33〜190）

画像所見:前医で撮影した副鼻腔単純CT（図3）では, 鼻中隔前方, 鼻中隔軟骨部の腫脹所見 $(24 \times 22 \mathrm{~mm})$ を 認めた。右副鼻腔は全て軟部陰影を認めたが骨破壊や石 


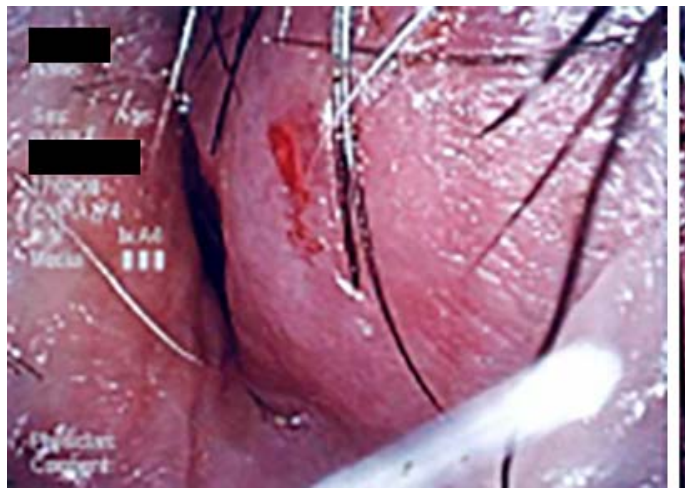

(a) 右鼻内

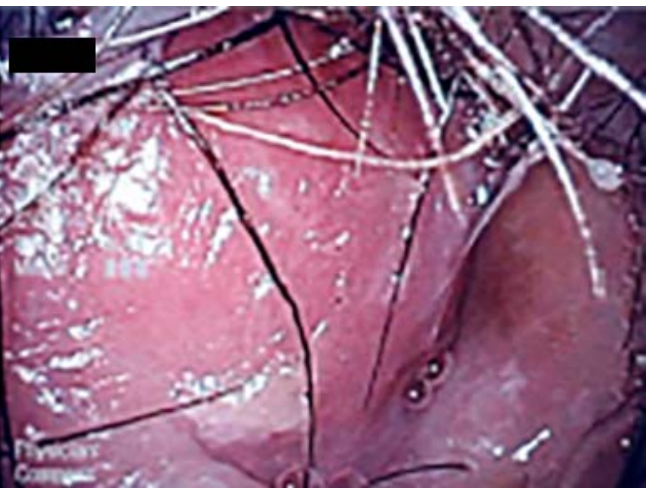

(b) 左鼻内

図2 初診時鼻内所見：鼻中隔の著明な発赤, 腫脹を認めた。

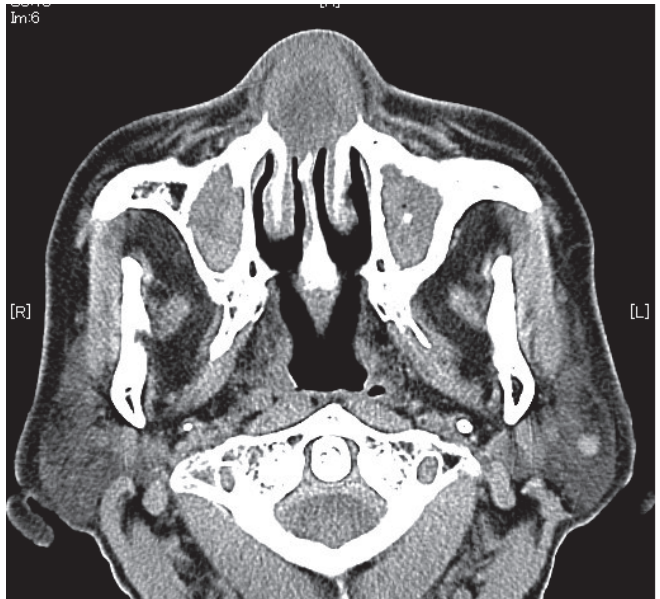

(a) 軸位断

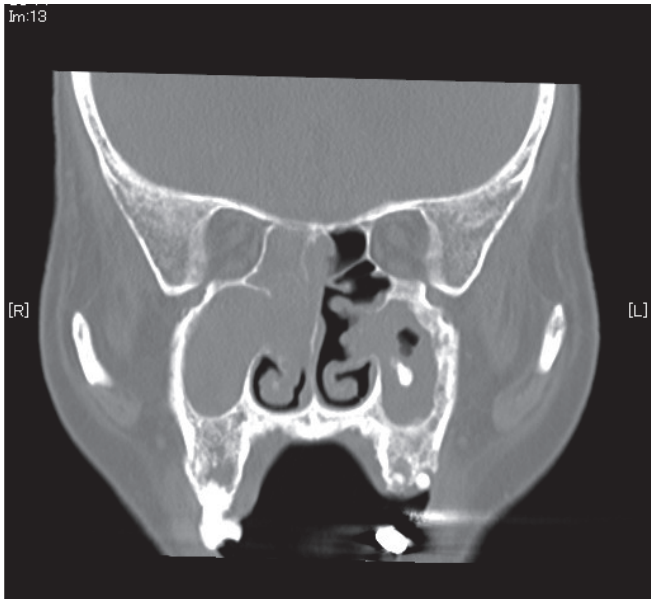

(b) 冠状断

図3 前医初診時副鼻腔単純CT所見。（a）軸位断 鼻中隔前方の腫脹所見を認めた。（b）冠状断 左上顎洞内には 石灰化陰影を伴う軟部陰影を認めた。右上顎洞，篩骨蜂巣にも軟部陰影を認めた。

灰化陰影はみられなかった。左上顎洞，前部篩骨蜂巣， 蝶形骨洞には軟部陰影を認め, 左上顎洞内には石灰化陰 影を認めたが，骨破壊はみられなかった。前医入院時に 撮影した胸部単純CT, 当院受診時の胸部単純レントゲン 写真では肺野に異常陰影は認めなかった。

経過：当科での診察所見，前医施行の副鼻腔CT所見 より鼻中隔膿瘍を疑った。当科にて受診当日に鼻中隔右 側より 18G針にて穿刺し $4 \mathrm{ml}$ の黄褐色膿汁が吸引され (図 4a), 鼻中隔膿瘍, 慢性副鼻腔炎, 慢性非浸潤性副鼻 腔真菌症疑いにて, 専門的治療を要すると判断し当科入 院とした。膿汁は細菌培養検査に提出した。局所麻酔下 に鼻中隔右側粘膜を垂直に切開し，ペンローズドレーン

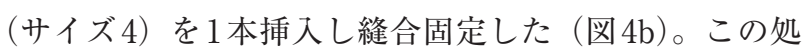
置により鼻中隔両側の腫脹の軽減を認めたため左側の切 開は行わなかった。認知症の状態から安静を保つのが 困難と予想されたため副鼻腔MRI検查は施行しなかっ
た。抗菌薬治療については, 血清梅毒反応が陽性のため, 院内の感染対策部にもコンサルトの上，鼻中隔膿瘍に対 する原因菌カバーと梅毒に対する抗菌薬治療を考えピペ ラシリンタゾバクタム（PIPC/TAZ） 13.5g/日の点滴投 与を開始した。しかし認知症のため点滴キープが困難で あったため,アモキシシリン（AMPC 250mg）4錠/日と アモキシシリンクラブラン酸（AMPC $250 \mathrm{mg} / \mathrm{CVA}$ $125 \mathrm{mg}$ ）2錠/日の内服投与に変更し，生理食塩水による 鼻中隔の洗浄も施行したが，自覚症状，局所所見，炎症 反応全て改善にそしかった。

第 4 病日になり，当科初診時に穿刺吸引で採取した鼻 中隔の膿の希釈検体の直接鏡検にて, 糸状菌を疑う所見 を認めたと検査部より報告があった（図5）。また，第 2

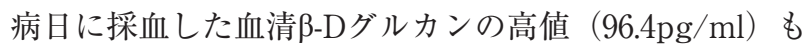
認められたため（正常值 $20 \mathrm{pg} / \mathrm{ml}$ 以下）, 抗菌薬不応性の 経過にも矛盾しないと考え, 真菌性鼻中隔膿瘍と診断し, 


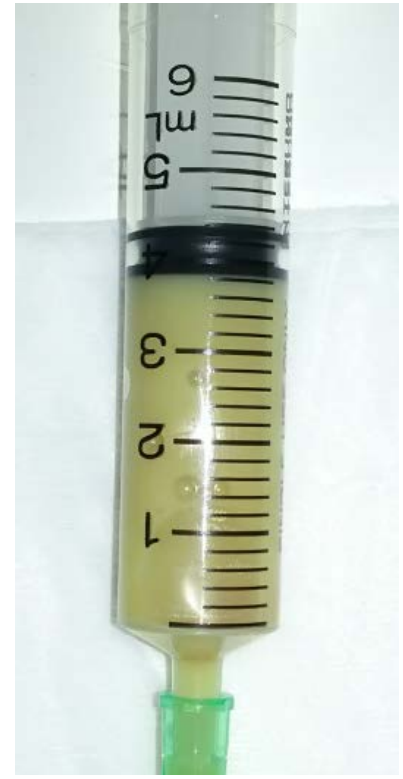

(a)

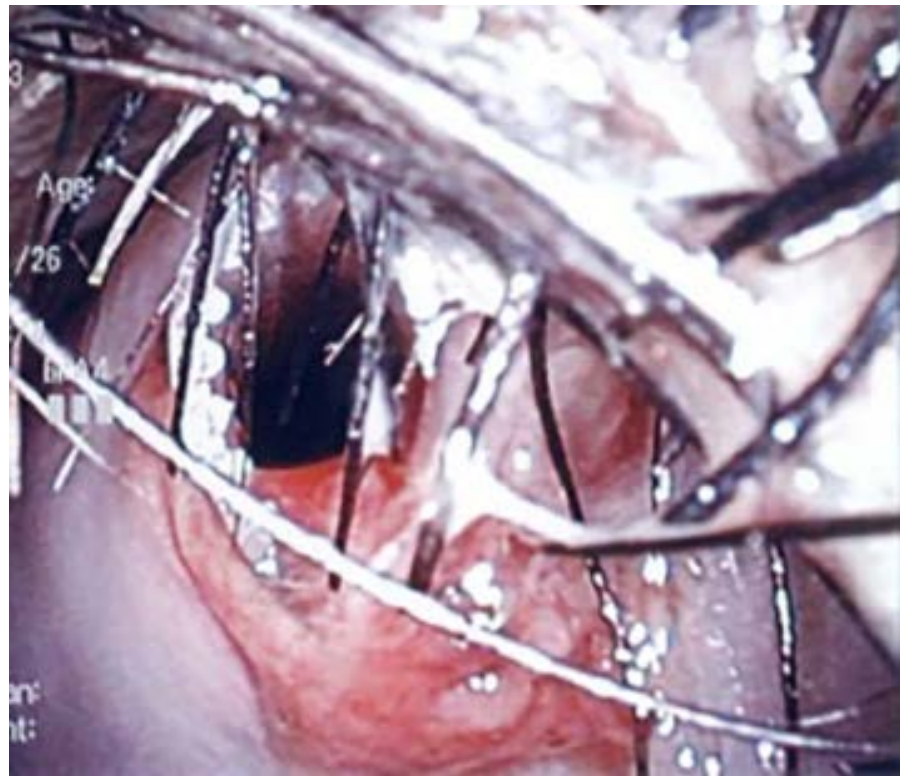

(b)

図4 鼻中隔穿刺，切開所見

（a）穿刺吸引で $4 \mathrm{ml}$ 排膿を認めた。

（b）鼻中隔右側ヘペンローズドレーンを留置した。

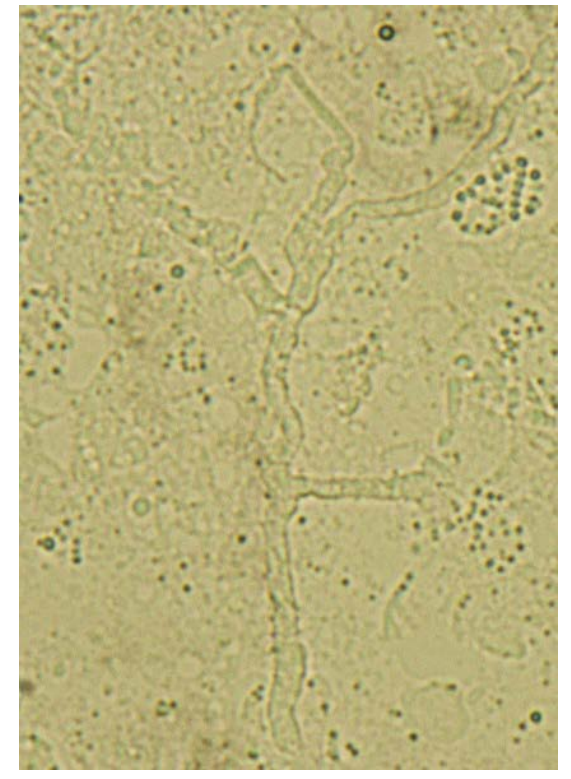

図5 鼻中隔の膿の希釈液直接鏡検所見 : 系状菌を疑う所見 を認めた。

ボリコナゾール (VRCZ) の投与をloading doseから開始 した $(300 \mathrm{mg}$ /回点滴投与, 1 日 2 回より，図 8 に投与経 過記載)。同時にアスペルギルスガラクトマンナン抗原検 查, カンジダマンナン抗原検査も追加した。また梅毒に ついて，罹患時期が不明であり認知症症状も強かったた め神経梅毒の可能性を疑い当院神経内科にコンサルトし たところ，本人の状態から髄液検査は施行できないが神 経梅毒が高率に疑われるためぺニシリンGカリウム
(PCG) 2400 万単位/日の 15 日間の投与とその後の長期ぺ ニシリン内服投与を指示され，第5病日より PCGの点滴 投与を開始した。

真菌性鼻中隔膿瘍に副鼻腔病変が関与している可能性 を疑い，第6病日に全身麻酔下に両内視鏡下副鼻腔手術 （ESS）と鼻中隔の生検を施行した。鼻中隔軟骨はすでに 部分的に溶解しており，両側上顎洞には乾酪様物質が認 められ，両上顎洞粘膜の他，開放した両前頭洞，前・後 篩骨蜂巣, 蝶形骨洞粘膜も病的浮腫を呈していた（図6）。 両上顎洞内の乾酪様物質を除去し，鼻中隔組織や副鼻腔 粘膜各部の生検を施行し終了した。

病理組織検査所見（図7）:鼻中隔軟骨には好中球浸潤 と真菌浸潤を認め, 両上顎洞内の乾酪様物質はAspergillus の菌塊であった。副鼻腔粘膜や鼻中隔の軟骨以外への組 織への真菌浸潤は認めなかった。

術後経過（図8）: 術後もVRCZ内服（400mg/日）を継 続した。鼻内にパッキングしたベスキチン $\mathrm{F}^{\circledR}$ 術後 2 日 で抜去し，生理食塩水による副鼻腔，鼻中隔の洗浄を連 日施行した。鼻内所見, 自覚症状改善ともに良好であっ た。第 4 病日に採血した血清アスペルギルス抗原は 2.7 と上昇が判明した（cut off index 0.5）。鼻中隔軟骨への 真菌浸潤遺残に対してデブリドマンも提示したが本人， 家族共に手術は希望せず投薬継続による治療を希望され た。鼻中隔ドレーンは 12 日間で抜去した。肝機能障害の ためVRCZを $200 \mathrm{mg}$ /日に減量したが, 血清 $\beta$-Dグルカン 上昇傾向があり副鼻腔造影CTを再検したが（図9), 鼻 


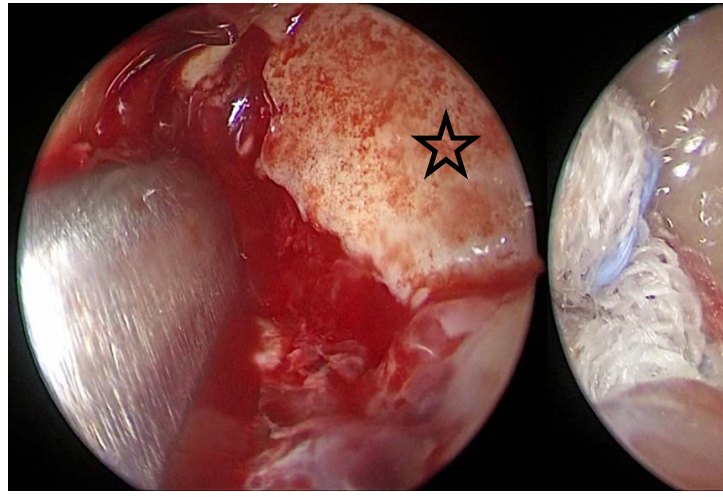

(a)

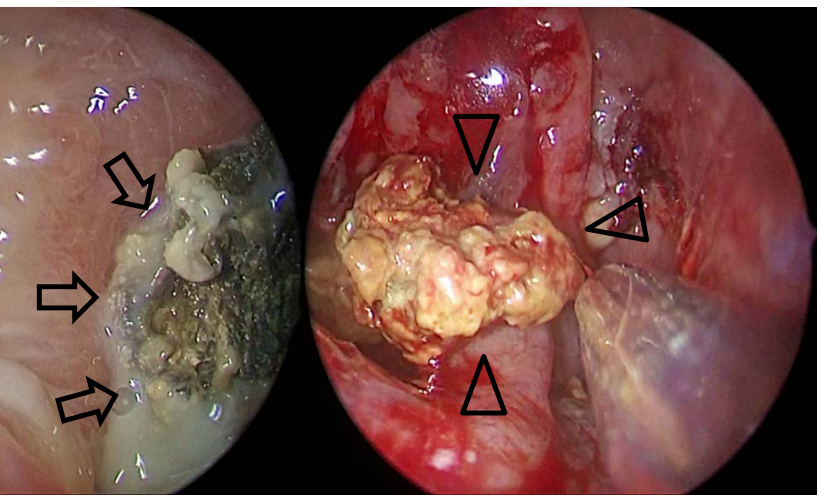

(b) (c)

図6 手術所見：(a) 鼻中隔軟骨は溶解し部分的に欠損していた（星印：鼻中隔軟骨)。(b) 左上顎洞内に乾酪様物質（矢印）を 認めた。（c）右上顎洞内にも乾酪様物質（矢頭）を認めた。

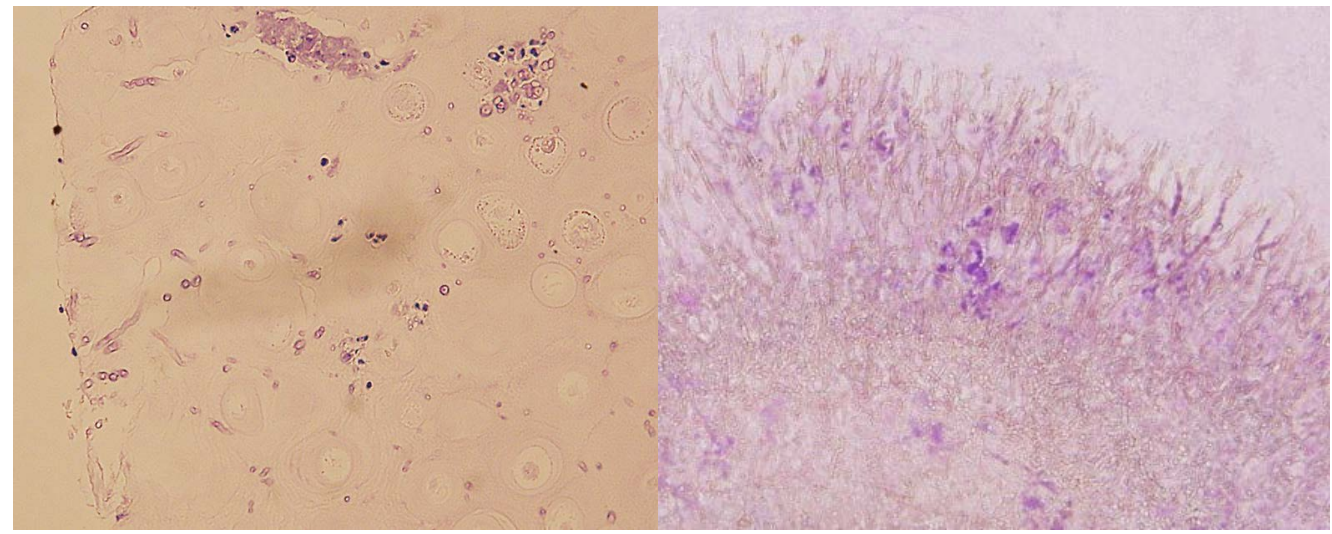

(a) (b)

図7 病理組織所見：(a) 鼻中隔軟骨, PAS染色, 400倍。軟骨への真菌浸潤を認めた。（b）左上顎洞内乾酪様物質, PAS染色，100倍。45に分岐し隔壁のある真菌塊を認めアスペルギルスと診断された。

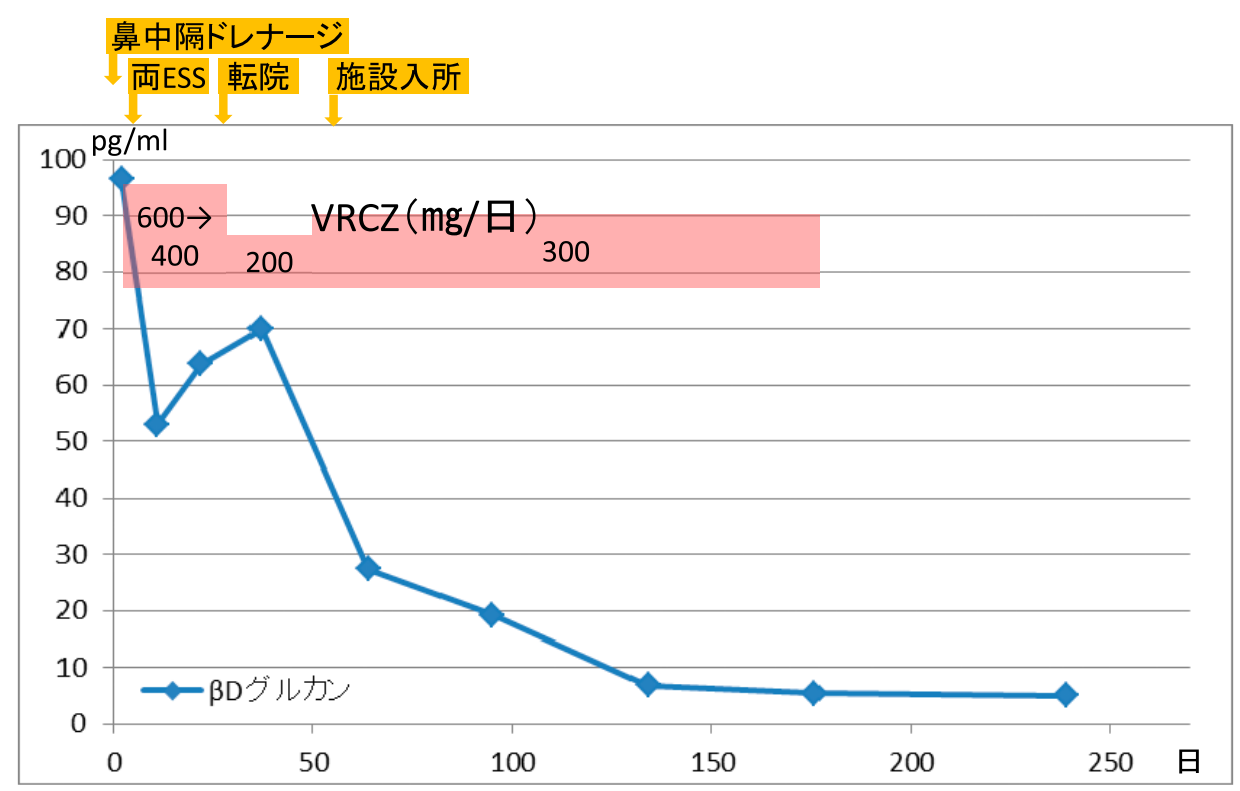

図8 臨床経過 


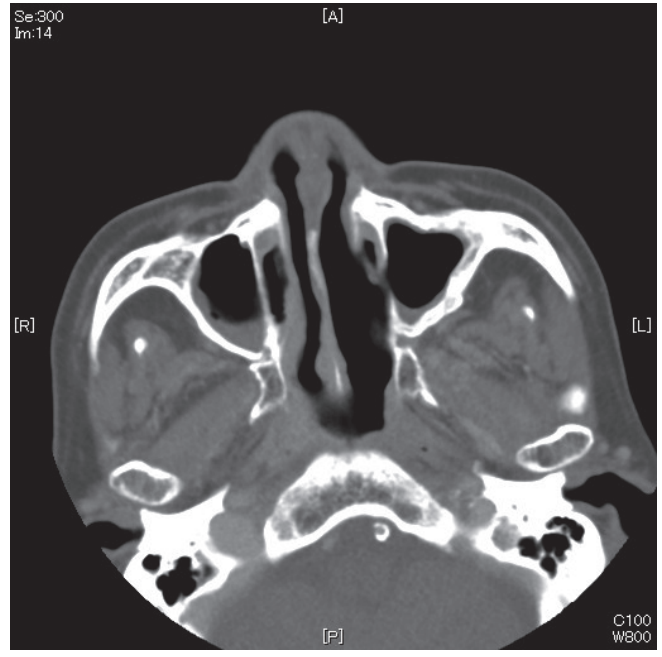

(a) 軸位断

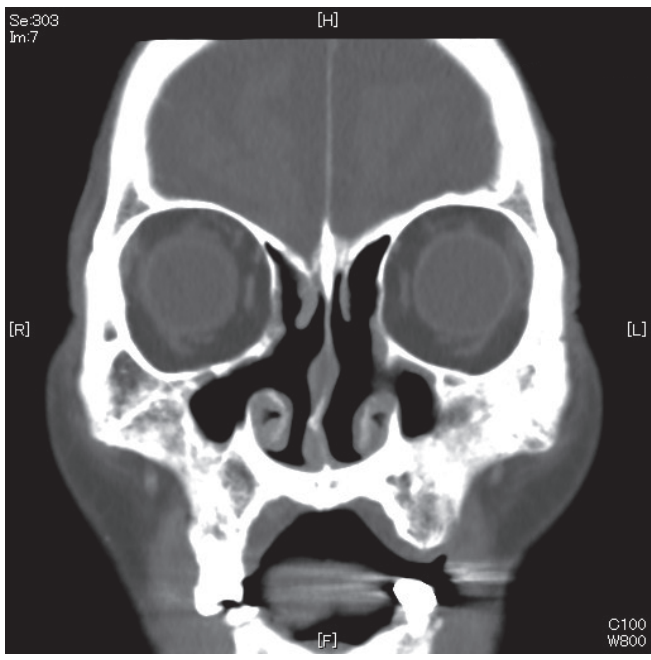

(b)冠状断

図9 副鼻腔造影CT所見 (術後)。（a）軸位断 鼻中隔に膿瘍の再燃は認めなかった。(b)

（b）冠状断 開放した副鼻腔 の含気は良好で周囲の骨破壊所見は認めなかった。

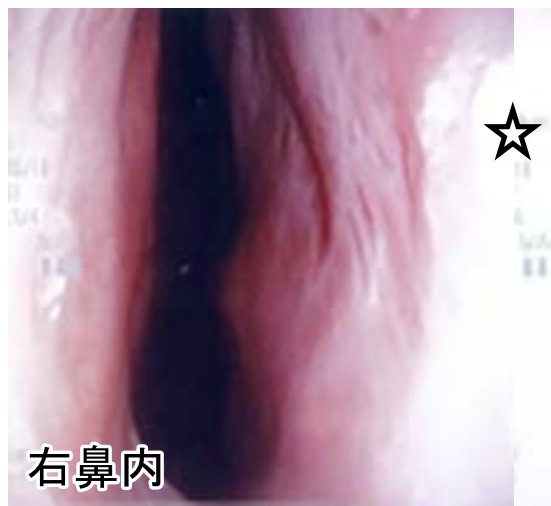

(a)

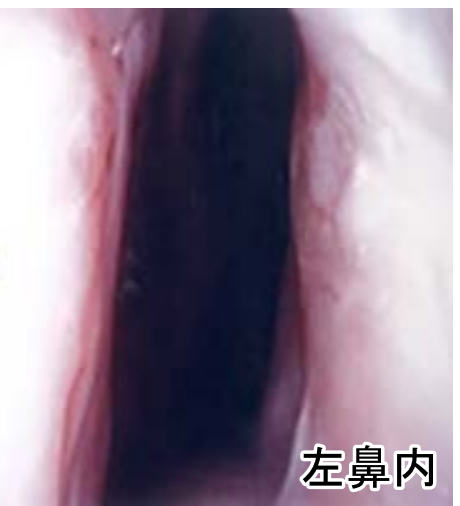

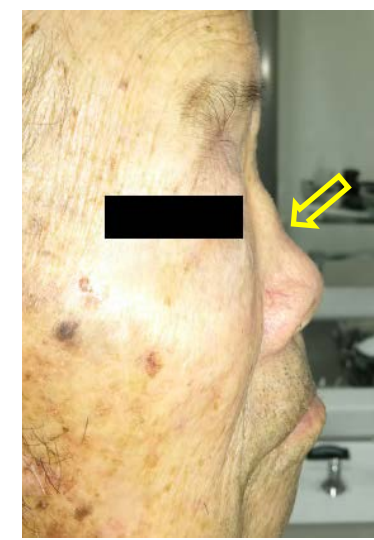

(b)

図 10 （a）治療終了後2か月時点の鼻内所見：鼻中隔（星印）の腫脹は認めない。（b）同外鼻所見：鞍鼻が残存した（矢印）。

中隔膿瘍の再発はなく鼻中隔周囲・副鼻腔周囲への浸潤 所見や骨破壊所見は認めず, VRCZを $300 \mathrm{mg} /$ 日に増量し

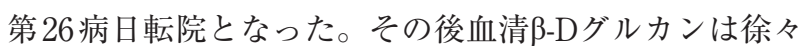
に減少し正常化した。鼻中隔の膿培養では当科初診から 33 日目にAspergillus fumigatusが同定され真菌性鼻中隔 膿瘍と確定診断され, 真菌MICではVRCZ $0.25 \mu \mathrm{g} / \mathrm{ml}$ あった。VRCZは6ヶ月間投与を行い終了した。梅毒に 対して続けていたAMPCの投与も6ヶ月間で終了した。 投薬終了後 2 か月時点でも鼻内所見は再発なく血清 $\beta-D$ グルカン值も正常值のまま経過しているが, 鞍鼻は残存 した（図10）。

\section{考察}

鼻中隔膿瘍は，抗菌薬の発達した現代では日常臨床で 遭遇することは稀である。成因から外傷性, 隣接臓器か らの感染波及, 特発性に分けられ ${ }^{1)}$, 頻度はそれぞれ $36.7 \%, 26.6 \%, 36.7 \%$ との報告がある ${ }^{2)}$ 。外傷による場合, 鼻中隔の軟骨膜下に血腫を形成し, 鼻中隔内圧が上昇し て鼻中隔軟骨への栄養血管が破綻し鼻中隔軟骨が虚血壊 死に陥り，細菌感染を合併して膿瘍形成に至ると考察さ れている ${ }^{3)}$ 。鼻中隔軟骨は，膿瘍形成による物理的な圧 力や虚血，炎症の影響などで24-48時間で壊死に陥ると いわれ ${ }^{4)}$ ，鞍鼻を残さないようにするためには，早期の 膿瘍のドレナージによる減圧, 消炎が必須である。 
表 1

\begin{tabular}{|c|c|c|c|c|c|c|}
\hline 報告者/年 & 年齢/性 & 基礎疾患 & 原因真菌 & 排膿処置 & 抗真菌薬（種類，投与期間） & 転帰 \\
\hline Dornbusch, et al $2005^{6}$ & 9/男性 & $\begin{array}{l}\text { 慢性骨䯣性白血病 } \\
\text { 慢性GVHD } \\
\text { 免疫抑制薬 }\end{array}$ & Fusarium verticillioides & 穿刺十再ドレナージ & L-AMB (IV) 32day & $\begin{array}{l}\text { 治癒 } \\
\text { 鞍鼻明記なし } \\
\text { 鼻中隔軟骨溶解 }\end{array}$ \\
\hline Walker, et al $2007^{5}$ & 64/男性 & $\begin{array}{l}\text { クローン病 } \\
\text { 肺線維症 } \\
\text { 免疫抑制薬 }\end{array}$ & Aspergillus flavus & 穿刺 $\rightarrow$ 切開 & $\begin{array}{l}\text { 種類記載なし } \\
\text { IV } 6 \mathrm{~W}\end{array}$ & $\begin{array}{l}\text { 鞍鼻なし } \\
\text { 経過観察 } 18 \mathrm{M} \\
\text { 再発なし }\end{array}$ \\
\hline 牧原ら 2013 & 86/男性 & $\begin{array}{l}\text { 糖尿病 } \\
\text { 脳梗塞 } \\
\text { OMI } \\
\text { 両蝶形骨洞真菌症（未治療） }\end{array}$ & Aspergillus flavus & 切開排膿, ドレーン留置 & $\begin{array}{l}\mathrm{VRCZ} \rightarrow \text { AMPH-B } \rightarrow \\
\mathrm{MCFG}(66 \text { day })+\mathrm{ITCZ} \\
(\text { po, 6M以上) }\end{array}$ & $\begin{array}{l}\text { 鞍鼻 } \\
\text { 経過観察 } 6 \mathrm{M} \\
\text { 再発なし }\end{array}$ \\
\hline 高倉ら 2014 & 75/男性 & 重度糖尿病 & Aspergillus & 切開排膿 & 記載なし & 外鼻変形 \\
\hline Patel, et al $2015^{9)}$ & 51/女性 & $\begin{array}{l}\text { 気管支喘息 } \\
\text { 経ロステロイド } \\
\text { 両上顎洞真菌症術後 }\end{array}$ & Scedosporium apiospermum & $\begin{array}{l}\text { 穿刺 } 3 \text { 回 } \rightarrow \text { 切開排膿, } \\
\text { カテーテル留置 }\end{array}$ & $\begin{array}{l}\text { AMPH-B (3day, irrigation) } \\
\text { VRCZ (po) 3M }\end{array}$ & $\begin{array}{l}\text { 治癒 } \\
\text { 経過観察 8M } \\
\text { 鞍鼻明記なし } \\
\text { 鼻中隔軟骨溶解 }\end{array}$ \\
\hline 本報告 2016 & 89/男性 & $\begin{array}{l}\text { 梅毒, 認知症 } \\
\text { 両上顎洞真菌症（未治療） }\end{array}$ & Aspergillus fumigatus & 切開排膿, ドレーン留置 & VRCZ $(\mathrm{IV} \rightarrow \mathrm{po}) 6 \mathrm{M}$ & $\begin{array}{l}\text { 鞍鼻 } \\
\text { 経過観察 } 8 \mathrm{M} \\
\text { 再発なし }\end{array}$ \\
\hline
\end{tabular}

L-AMB: liposomal amphotericin B, AMPH-B: amphotericin B, VRCZ: voriconazole, ITCZ: itraconazole, MCFG: micafungin

鼻中隔膿瘍の原因微生物としては細菌性が多く，上村 らは頻度としてはブドウ球菌 $(39.3 \%)$, 肺炎球菌 $(25.0 \%)$, 連鎖球菌 $(12.5 \%)$ と報告している ${ }^{1)}$ 。真菌による鼻中隔 膿瘍の報告は稀であり，涉猟し得た範囲では，原因が真 菌と確定された症例は本例を含め6 例 ${ }^{5-9)}$ のみであった (表1)。全例で何らかの合併症があり, 慢性骨髄性白血 病とそれによる慢性GVHD・免疫抑制薬使用 ${ }^{6)}$, 肺線維 症・クローン病と免疫抑制薬使用 ${ }^{5)}$, 気管支喘息発作の ための副腎皮質ステロイド内服 ${ }^{9)}$ と 6 例中 3 例で免疫不全 状態が認められた。2例は糖尿病の合併を認め ${ }^{7.8)}, 3$ 例は 慢性非浸潤性副鼻腔真菌症（本例を含め 2 例は上顎洞真 菌症, 1 例は蝶形骨洞真菌症 (後に侵潤型真菌症へ移行)) の合併を認めた ${ }^{7.9)}$ 。両上顎洞真菌症術後に真菌性鼻中隔 膿瘍を発症した報告では, 初回ESS時の鼻中隔への外傷 の関与が示唆されている ${ }^{9)}$ 。蝶形骨洞真菌症から真菌性 鼻中隔膿瘍を生じた例では解剖学的に連続した真菌感染 の伝播が原因と考察されている ${ }^{7)}$ 。免疫不全や糖尿病な どの易感染性宿主, 隣接臓器疾患である副鼻腔真菌症の 合併は鼻中隔膿瘍において真菌を原因として疑うポイン

トになると考えられる。

原因真菌は6例中4例はAspergillusであり ${ }^{5,7,8)}$, Fusarium が1例 ${ }^{6)}$, Scedosporiumが1例 ${ }^{9}$ であった。治療は全例で 膿瘍のドレナージと抗真菌薬の全身投与が施行されてい た。穿刺排膿を行った症例も膿の再貯留のため再穿刺や 最終的に切開排膿が施行され, 6 例中 5 例で結果的に切開 によるドレナージが施行されていた。切開後, カテーテ ルを留置してアンホテリシンBによる鼻中隔の局所潅流 療法を施行した報告もみられた ${ }^{9)}$ 。全身投与された抗真
菌薬の種類は様々であったが, 投与期間は 1 \% 月に及 んでいた。最終的な転帰として, 鞍鼻は 6 例中 3 例で認め られ ${ }^{7.8)}$, 鞍鼻を認めなかったのは 1 例 ${ }^{5)}$, 残りの 2 例は鞍 鼻について明記はなかったが鼻中隔軟骨の破壊がみられ ていたため鞍鼻を呈していた可能性は否定できない。通 常の鼻中隔膿瘍の後遺症としての鞍鼻は $29 \%$ で認められ $3^{2)}$ という報告と比較すると，少なく見積もって真菌性 鼻中隔膿瘍は $50 \%$ の鞍鼻残存であり, 高率である。本例 は鞍鼻が残存したが，当科受診時点で発症から9日以上 が経過しており，すでに鼻中隔軟骨の壊死は進んでいた と考えられ，治療の成否に関わらず鞍鼻は避けられなか ったと思われる。

本例の発症機序について考察する。真菌が組織に浸潤 すると様々な組織反応が生じるが，好中球機能が残って いる場合，アスペルギルスやカンジダ，ムコールでは好 中球浸潤による化膿性炎症を生じる ${ }^{10)}$ 。加齢により好中 球の貪食能や遊走能は低下し，スーパーオキサイド産生 も減少し殺菌能は低下する ${ }^{11}$ 。本例は, 糖尿病の合併や 免疫グロブリン低下, HIV感染は認めず，検査上は免疫 不全を示唆する所見は得られなかったが，89歳と高齢 だったことは免疫老化の点で易感染性であると考えら れ, 本例の発症要因の一つと思われる。真菌の感染経路 については, 蝶形骨洞には真菌塊は認めず, 蝶形骨洞粘 膜にも真菌浸潤はなかったため, 真菌が鼻中隔が接する 蝶形骨洞から直接伝播したとは考えにくい。本疾患発症 前には明らかな外傷のエピソードはなく，鼻部に打撲痕 や紫斑も認めなかったが, 発症前から鼻汁が多く頻回に 擤鼻していたことが家族の話で明らかとなった。擤鼻で 
鼻中隔前方に軽微な裂傷を生じることは十分に考えられ る。鼻ほじり癖については本人からも家族からも明確な 確認は困難であった。本例の鼻中隔膿瘍の局在は鼻中隔 前方の鼻中隔軟骨部であり, 発症機序としては高齢で免 疫能が低下している状態で反復する擤鼻により生じた無 自覚な鼻中隔の軽微な外傷部位に上顎洞真菌症由来の膿 が接触し真菌が鼻中隔組織へ感染し発症した可能性が考 えられる。

真菌性鼻中隔膿瘍に対する早期の適切な抗真菌薬投与 のためには診断が重要だが, 実際には早期診断は難しい。 微生物学的検查として膿の鏡検や培養, 血清学的診断と

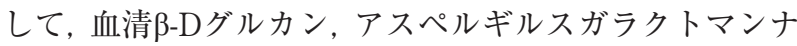
ン抗原，カンジダマンナン抗原等が挙げられるが，培養

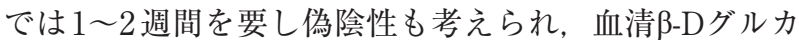
ンやアスペルギルスガラクトマンナン抗原, カンジダマ ンナン抗原は 2 4日を要する。本症例では膿の直接鏡検 で第4病日に診断の手がかりを得られたが，実際には膿 採取当日より鏡検を施行しており，膿の濃度が高すぎた ため当初は診断に結び付く情報が得られず，コンタミ ネーションに注意して希釈して鏡検を行うことで糸状菌 を疑う所見を得ることができた。今後同様の症例があれ ば，臨床検查部と密に連携し膿の採取日から同様の検查 を行うことでより早期に真菌による膿瘍を疑い治療介入 できる可能性がある。

治療は膿瘍のドレナージと抗真菌薬投与が基本とな る。穿刺排膿を施行し，再度膿譻留が生じた場合に穿刺 を反復している報告もあるが，最終的には穿刺のみでは 不十分で切開排膿を要した症例もあり，また好気環境に できる, 確実な排膿を得られる, 洗浄可能などの点で積 極的に切開排膿を行うべきである。鼻中隔組織自体への 真菌浸潤が証明された症例は本例を含め 2 例あったが ${ }^{8}$, いずれも鼻中隔軟骨への浸潤であった。このような場合 にデブリドマンが望ましいかは現時点で明らかでない。 他の 4 例については鼻中隔組織の病理学的評価自体が行 われていない。本例における真菌浸潤のあった遺残鼻中 隔軟骨をデブリドマンしなかったことの適否の判断には 更に長期間のフォローアップが必要である。抗真菌薬投 与の投与期間に定まったものはないが, 長期間に及ぶこ とも考慮し，最適な薬剂選択のために真菌MICを積極的 に利用すべきである。本例ではイトラコナゾール（ITCZ) のMICがより低值 $(0.125 \mu \mathrm{g} / \mathrm{ml})$ だったが, ITCZ内用液 製剤より錠刻内服を希望されたため, 使用可能かつ感受 性のあったVRCZを継続の方針とした。長期間の抗真菌 薬投与時には肝機能障害を始めとして副作用の確認を意 らないようにしなければならない。本例では鼻中隔軟骨
への真菌浸潤遺残を考慮して6ヶ月間のVRCZ長期投与 を選択し，肝機能障害のため投与量調整を要したが完遂 し得た。長期投与にあたっては，本例では実施していな いが，VRCZの血中濃度測定も考慮される。

予後については，後遺症として鞍鼻は多いが，膿瘍の ドレナージと抗真菌薬投与により改善は良好といえる。 本検討から，鼻中隔膿瘍症例で，易感染性宿主である場 合や糖尿病合併例，副鼻腔真菌症合併時は，鞍鼻残存を できるだけ避けるためにも，漫然と抗菌薬の投与を行わ ず，当初より真菌性の可能性も念頭に置いた診療手順を 踏むことが必要である。

\section{まとめ}

両上顎洞慢性非浸潤性副鼻腔真菌症に合併した稀な真 菌性鼻中隔膿瘍の1例を経験した。組織学的に鼻中隔軟 骨へのアスペルギルスの浸潤が確認されたが，膿瘍の切 開排膿ドレナージと6r月間のVRCZの投与で治癒した が鞍鼻が残存した。易感染性宿主や糖尿病合併例，副鼻 腔真菌症合併例では真菌も鼻中隔膿瘍の原因として初め から想起して対応することが必要である。

\section{謝 辞}

稿を終えるにあたり，本症例の微生物学的診断にご尽 力いただいた星総合病院臨床検查部鈴木弘子先生に深謝 いたします。

本論文の要旨は第55回日本鼻科学会総会ならびに学術 講演会（2016年10月，宇都宮市）にて口演した。

利益相反に該当する事項：なし

\section{参考文献}

1）上村卓也, 藤巻龍美, 岸 澄子 : 特発性鼻中隔膿瘍 の 1 症例。耳喉 $1968 ； 40 ： 613-617$.

2）山田一美，瀧本 勲，稲福 繁，他：鼻中隔膿瘍の 1例. 耳鼻臨床 $1985 ； 78 ： 1302-1307$.

3) Ambrus PS, Eavey RD, Baker AS, et al : Management of nasal septal abscess. Laryngoscope 1981 ; $91: 575-582$.

4) Matsuba HM, Thawley SE : Nasal septal abscess: Unusual causes, complications, treatment, and sequelae. Ann Plast Surg 1986 ; 16 : 161-166.

5) Walker R, Gardner L, Sindwani R : Fungal nasal septal abscess in the immunocompromised patient. Otolaryngol Head Neck Surg 2007 ; 136 : 506-507.

6) Dornbusch HJ, Buzina W, Summerbell RC, et al : 
Fusarium verticillioides abscess of the nasal septum in an immunosuppressed child: Case report and identification of the morphologically atypical fungal strain. J Clin Microbiol 2005 ; 43 : 1998-2001.

7）牧原靖一郎, 竹内彩子, 山本美紀, 他：鼻中隔膿瘍 を伴った浸潤型蝶形骨洞アスペルギルス症例．耳鼻 臨床 $2013 ； 106 ： 213-220$.

8）高倉大匡, 舘野宏彦, 藤坂実千郎, 他：当科で経験
した鼻中隔膿瘍 2 症例。日鼻誌 $2014 ; 53 ： 437$.

9) Patel R, Richard RO : Fungal septal abscess complicating maxillary sinus fungus balls in an immunocompetent host. Allergy Rhinol 2015 ; 6 : e184-e187.

10）若山恵：深在性真菌症における病理診断の役割. 診断病理 $2016 ; 33: 205-214$.

11）石井隆弘，倉井華子：高齢者はなぜ感染症に罹患し やすいのか. 内科 $2014 ; 114 ; 755-758$. 